\title{
Improving Writing Ability and Independent Learning Using Problem Based Learning (PBL) Assisted by Serial Image Media
}

\author{
Ika Mustika* \\ Indonesian Language and Literature \\ Education Study Program \\ IKIP Siliwangi \\ Cimahi, Indonesia \\ mestikasaja@ikipsiliwangi.ac.id
}

\author{
Teti Sobari \\ Indonesian Language and Literature \\ Education Study Program \\ IKIP Siliwangi \\ Cimahi, Indonesia \\ tetisobari@ikipsiliwangi.ac.id
}

\author{
Ratih Sapdiani \\ Indonesian Language and Literature \\ Education Study Program \\ IKIP Siliwangi \\ Cimahi, Indonesia \\ ratihsapdiani@gmail.com
}

\begin{abstract}
This research was conducted due to the low ability of students in writing procedural texts and the lack of independent learning of students. This is due to the difficulty of students developing procedural texts in supporting the achievement of learning objectives and the lack of student motivation to learn independently. This study aims to determine the increase in the ability to write procedural texts and the independent learning of students using problem-based learning $(P B L)$ assisted by serial image media. This research method is a quasi-experimental type nonequivalent control group design. The research subjects were students of class VII A and VII B at one of the Cimahi high schools, each with a total of 30 people who were not randomly selected. The instruments used to collect data were a test of the ability to write procedural texts and a learning independence questionnaire. The results showed that the increase in the ability to write procedural text and the learning independence of students using $P B L$ assisted by serial image media was better than using $P B L$ only. In other words, $P B L$ assisted by serial image media could improve the ability to write procedural texts and the learning independence of students.
\end{abstract}

Keywords-writing skills, independent learning, problembased learning (PBL), serial image media

\section{INTRODUCTION}

Writing as an aspect of language activities has an important role in today's life. Writing skills are an absolute requirement for someone to be involved in various fields of activity [1]. This implies that writing skills have a very important role in everyday life.

Regarding that, Ken Hyland explained that writing is seen as a very important language skill that must be mastered by students [2]. Writing skills are not just giving birth to thoughts or feelings, but also expressing ideas, views, knowledge about various things in writing using language media. Paola Uccelli et al explained that students' knowledge of words that must be used in writing is an indicator of a set of language skills that must be mastered [3]. Thus, writing skills are not a simple activity.

Referring to the 2013 Curriculum for Indonesian in Junior High Schools, the procedural text is one type of text that students must master. Procedure text is a text that contains systematic steps whether to do, use, create, or play [4]. By reading the procedure text, the reader can find out the steps to make or do something correctly to avoid procedural errors [5].
The structure of the procedural text is divided into the formulation of objectives (introduction), discussion steps, and closing [4]. Endah T. Priyatni explained that the linguistic characteristics of complex procedures are (1) using numbering indicating sequences or stages, (2) using words that indicate commands, and (3) using words to describe conditions [6].

Based on the results of interviews with class VII Indonesian teachers, the problem faced by the teacher related to the low ability of students to write procedural texts was the difficulty of students pouring out a step in carrying out, using, making procedural texts sequentially by paying attention to linguistic aspects that were following the rules. Developing a procedural text is still considered difficult material to do. The factors that become the problems of students in producing procedural text include (1) students having difficulty in sorting the parts and steps of making a procedural text, (2) students still having difficulty in developing a procedural text by paying attention to linguistic aspects [7]. Also, learning to write is more emphasized on the results in the form of writing, not on the process when students write. Dadang Anshori conveyed that the low writing ability is due to the weak writing learning system in schools [2]. Students never get how to write correctly (writing process).

Another fact, learning has not involved the independence of students in learning as a whole. Afandi explained that at least one of the causes for the low independence of learning is the learning system that does not require students to take an active role in finding the information needed in the learning process [8]. Student learning activities tend to be in the form of physical activities such as listening and writing information conveyed by the teacher, while other aspects of independent learning are not given enough attention. Students who have independence do not just listen and absorb but act [9].

One of the strategies that teachers can do to overcome the above problems is by applying Problem Based Learning $(P B L)$ assisted by serial image media in the classroom. The learning approach and instructional media are aspects that can support student learning activities [8].

$P B L$ is characterized by real problems as a context for students to learn to think critically [10]. This approach focuses on tracing the root of the problem and solving the problem. In, $P B L$ students are faced with problems related to the realities of life so that they do not only learn areas of knowledge, but also experience and feel [9]. Furthermore, the advantages of 
$P B L$, learning is more meaningful because students are faced with situations of applying concepts, integrating knowledge and skills of students, and can increase internal motivation to learn [9]. M. Hosnan suggests the stages of $P B L$ namely student orientation to problems, organizing students to learn, guiding individual and group investigations, developing and presenting work, and analyzing and evaluating the problemsolving process [7]. Several studies have shown that learning with $P B L$ very effective in improving student's writing skills in types of texts that require logical thinking, including procedural text [7], exposition text [11], explanatory text [12], observation report text [13], and description text [14].

The application of the learning approach associated with the use of instructional media can also support the improvement of learning independence. $P B L$ accompanied by picture media can improve students' learning independence in biology learning for class XI IA2 Senior High School 3 Surakarta academic year 2009/2010 on sub-material in the reproductive system [15]. The use of learning media is able to present authentic problems in the form of objects that are not directly observed or abstract material [16].

The above shows that $P B L$ explanation is proven to be able to improve the ability to write various types of texts such as procedural texts, exposition texts, explanatory texts, observation report texts, and descriptive texts. Also, the application $P B L$ of serial image-assisted can increase learning independence in Biology learning. Meanwhile, this study focuses on improving the ability to write procedural texts associated with independent learning using $P B L$ assisted by serial image media.

$P B L$ assisted by image media has the potential to improve the ability to write procedural texts and the students' learning independence. At the beginning of the lesson, a series of pictures is presented to stimulate and trigger students to think. This requires students to have an independent nature in learning so that they will not feel hopeless in facing problems and encourage students to choose suitable strategies to solve these problems. Through $P B L$ students are required to be skilled at asking questions and expressing opinions, finding relevant information from hidden sources, looking for various alternative ways to get solutions, and determining the most effective way to solve problems [17]. This is in accordance with the characteristics that exist in independent learning. In addition, the application of serial image media can present authentic problems and can stimulate students to learn. Serial image media is an intermediary in the form of a sequence of images used to convey messages to make it easier for students to learn. observe objects directly. With image media students learn more actively and achieve the ultimate goal of the learning process, namely increased learning outcomes.

Based on the description above, the formulation of this research is to find out: Is the improvement in the ability to write the procedural text of students using $P B L$ assisted by serial image media better than using $P B L$ only? Is increasing student learning independence using $P B L$ assisted by serial image media and $P B L$ only?, and Is there an association between the ability to write procedural texts and the students' learning independence in the post-test experimental class.

\section{METHODS}

This type of research is quantitative research. The research method used is the experimental method. The experimental method is a systematic method for building relationships that contain causal phenomena. The research design used was the nonequivalent control group design. This design uses two sample groups that are not randomly selected and are considered the same in all relevant aspects and the difference is only in the treatment given to the experimental group.

The population of this study was grade VII students at one of the Cimahi high schools registered in the 2019/2020 school year. The number of students enrolled is 210 people spread over seven classes. The research sample was taken by using the purposive sampling technique. Class VII $\mathrm{A}$ as the experimental class, and class VII B as the control class. There are two variables in this research, namely the first variable (X1) is the ability to write procedural text and the learning independence of grade VII students using PBL assisted by serial image media. The second variable (X2) is the ability to write procedural text and the learning independence of grade VII students using PBL only.

The instruments used in this study were a test of the ability to write procedural texts and a test to measure learning independence. The instrument has been validated by an expert and through the calculation of instrument calibration using anates software. The test of the ability to write procedural texts consisted of a test of knowledge and a test of skills in writing procedural texts. The knowledge test of writing procedure text consists of 20 multiple choice questions and 1 essay on the procedural text writing skills test. Meanwhile, the test to measure learning independence is a closed questionnaire with a statement totaling 20 items.

This research data collection technique was carried out twice, namely in the experimental class and the control class. The prerequisite analysis test was carried out before analyzing the data. The analysis requirements test carried out in this study were the normality test and the homogeneity test of the data. The data normality test was conducted to determine whether the data group was normally distributed or not, while the data homogeneity test was carried out to determine whether the data had homogeneity or not. The data normality test was performed using the Kolmogorov-Smirnov test. After the two prerequisite tests were carried out on the pretest and posttest data and the sample was declared normal and homogeneous, it was continued with hypothesis testing. Hypothesis testing was carried out on the pretest and posttest data. The hypothesis test used is the t-test.

\section{RESULTS AND DISCUSSION}

\section{A. Results}

The results of this experimental study began with students in the experimental class and the control class given a pre-test of their ability to write procedural texts and learning independence, after which the treatment was given a post-test of their ability to write procedural texts and independent learning. In the experimental class, they were treated using PBL assisted by serial image media and in the control class using PBL only. 
Implementation of PBL assisted by serial image media in the experimental class for six meetings. Likewise, in the control class. At the first meeting, a pretest was carried out and at the sixth meeting, a posttest was carried out. The second meeting to the fifth meeting was filled with the learning process of understanding the characteristics of the procedure text, the structure of the procedural text, the rules for the language of the procedural text, and writing the procedure text. Students are divided into 6 groups, each consisting of 5 people. At the problem orientation stage, students are given a worksheet that contains a series of pictures related to the procedural text material. Draw a series of problems presented to students. In the stage of organizing learning, students observe a series of pictures to determine what to do with the series images. In the stage of guiding individual and group investigations, students carry out activities to write procedural texts independently. In the stage of developing and presenting the work, students present the work of writing a procedural text. Furthermore, the results of writing a procedural text are evaluated jointly with the help of the teacher. With these stages, PBL assisted by serial image media can be implemented in learning. Meanwhile, the learning stages of writing procedural text in the control class did not use serial image media.

Based on the results of data processing, the results of the ability to write procedural texts and independent learning using the PBL assisted by serial image media and PBL only are presented in Table I.

TABLE I. Results of ABILITy to Write Procedure TEXT AND LEARNING INDEPENDENCE

\begin{tabular}{|c|c|c|c|c|c|c|c|c|c|c|c|c|}
\hline \multirow[t]{3}{*}{ Aspect } & \multicolumn{6}{|c|}{ PBL Assisted Image Media Series } & \multicolumn{6}{|c|}{ PBL Only } \\
\hline & \multicolumn{2}{|c|}{ Pre Test } & \multicolumn{2}{|c|}{ Pos Test } & \multicolumn{2}{|c|}{ N-Gain } & \multicolumn{2}{|c|}{ Pre Test } & \multicolumn{2}{|c|}{ Pos Test } & \multicolumn{2}{|c|}{ N-Gain } \\
\hline & $\overline{\bar{x}}$ & $\mathbf{S}$ & $\overline{\bar{x}}$ & $\mathbf{S}$ & $\bar{x}$ & $\mathbf{s}$ & $\bar{x}$ & $\mathbf{s}$ & $\overline{\bar{x}}$ & $\mathbf{S}$ & $\bar{x}$ & $\mathbf{s}$ \\
\hline KMT & 57,47 & 5,48 & 86,03 & 6,71 & 0,67 & 0,14 & 58,99 & 3,89 & 80,30 & 9,52 & 0,52 & 0,22 \\
\hline KMDR & 48,63 & 6,22 & 65,83 & 5,28 & 0,33 & 0,11 & 50,87 & 4,84 & 58,97 & 2,57 & 0,16 & 0.096 \\
\hline
\end{tabular}

Information:

KMT : Ability to Write Procedure Text, maximum score of KMT is 100

KMDR: Learning Independence, the maximum score of KMDR is 100 .

Based on Table I, the N-gain average value of the ability to write procedural text for the PBL class assisted by serial image media is 0.67 with a standard deviation of 0.11 , and for the PBL class, only the average value is 0.52 with a deviation the standard of 0.096. This shows a difference of 0.15 , so it is predicted that there is a difference in the increase in students' ability to write procedural text between those whose learning uses the PBL assisted by serial image media and PBL only,

Whereas for the $\mathrm{N}$-gain average of learning independence for the PBL class assisted by serial image media is 0.33 , and the average $\mathrm{N}$-gain value for the PBL class only is 0.16 , so it is predicted that there is a difference in student learning independence between those with learning. using PBL using serial image media and PBL only. However

To prove this prediction, it must be tested using inferential statistics, namely the t-test, by first testing the prerequisites, namely the normality and homogeneity test.

To test for normality the Kolmogorov-Smirnov test was used, with the test criteria if the sign value. $>0.05$, then the data is normally distributed and if the value is sign. $<0.05$, then the data are not normally distributed. Based on the test results, the following results were obtained: the N-Gain normality test was able to write the experimental class procedural text based on statistical calculations. 296, df 30,

The sign value is 0,000 and for the control class the statistical calculation is .222 , df 30 with a sign value of 0.001 , because the sign value. both classes are smaller than 0.05 , it is concluded that the data for the two classes are not normally distributed.

Henceforth, the Mann-Whitney test was carried out to test the hypothesis. The hypothesis being tested is formulated as follows.

- Ho : There is no difference in the increase in the ability to write procedural texts of students whose learning uses PBL assisted by serial image media and PBL only.

- $H_{1} \quad:$ The improvement of the ability to write procedural texts of students whose learners use PBL assisted by image media is better than PBL only.

The test criteria accept Ho if the sig value,> 0.05. Based on the results of data processing, the results are as shown in table below.

TABLE II. MANN-WhITNEY TEST RESUlTS FOR ABILITY TO WRITE PROCEDURE TEXT

\begin{tabular}{|c|c|c|c|}
\hline & & & $\begin{array}{c}\text { Gain } \\
\text { Score }\end{array}$ \\
\hline \multicolumn{3}{|c|}{ Mann-Whitney U } & 237.000 \\
\hline \multicolumn{3}{|c|}{ Wilcoxon W } & 702.000 \\
\hline \multicolumn{3}{|c|}{$\mathrm{Z}$} & -3.162 \\
\hline \multicolumn{3}{|c|}{ Asymp. Sig. (2-tailed) } & .002 \\
\hline \multirow{3}{*}{$\begin{array}{l}\text { Monte Carlo Sig. } \\
\quad \text { (1-tailed) }\end{array}$} & \multicolumn{2}{|l|}{ Sig. } & $.000^{\mathrm{b}}$ \\
\hline & \multirow[t]{2}{*}{$\begin{array}{l}\text { 95\% Confidence } \\
\text { Interval }\end{array}$} & $\begin{array}{l}\text { Lower } \\
\text { Bound }\end{array}$ & 0.000 \\
\hline & & $\begin{array}{l}\text { Upper } \\
\text { Bound }\end{array}$ & .049 \\
\hline
\end{tabular}

From Table II, the sign value is obtained. (1-tailed) of 0.00 , because of the sign value. $<0.05$, then Ho is rejected, which means the increase in the ability to write procedural texts of students whose learners use PBL assisted by serial image media is better than PBL only.

Furthermore, it is tested in inferential statistics for independent learning, by first testing the prerequisites, namely the normality and homogeneity test. To test for normality the Kolmogorov-Smirnov test was used, with the test criteria if the sign value. $>0.05$, then the data is normally distributed and if the value is sign. $<0.05$, then the data is not normally distributed, based on the test results obtained the following results, the N-Gain normality test for learning independence 
obtained a statistical calculation of 094, df 30, and a sign value of 0.200 and for the control class the statistical calculation is 158 , df 30 the sign value is 0.001 , because the sign value. both classes are smaller than 0.053 , it is concluded that the data for the two classes are normally distributed.

The homogeneity test was then carried out. Based on the results of the processing, the results of the homogeneity test of learning independence are F 448, Df1 1, Df2 58, the sign value. of 0.506 , because the sign value $>0.05$, the variance of the two groups is homogeneous because the data is normally distributed and homogeneous, then it is followed by the t-test. The hypothesis being tested is formulated as follows.

- Ho : There is no difference in the improvement of the learning independence of students whose learning uses PBL assisted by serial image media and PBL only.

- $H_{1}:$ Increased learning independence of students whose learners use PBL assisted by picture media is better than PBL only

The test criteria accept Ho if the sig value,> 0.05. Based on the results of data processing, the results of the t-test for independent learning are $\mathrm{t} 6,377$, df 58, and a value of sign,000. From Table II, the sign value is obtained. (1-tailed) is obtained at $0.00 / 2=0.000$, because of the sign value. $<0.05$, then Ho is rejected, which means the increase in the learning independence of students whose learners use PBL assisted by serial image media is better than PBL only.

Next will be discussed the association between the ability to write procedural texts with students' learning independence. Based on the results of data processing, the results are obtained in Table III.

TABLE III. RESULTS OF THE ASSOCIATION BETWEEN THE ABILITY TO WRITE PROCEDURE TEXT AND LEARNING INDEPENDENCE

\begin{tabular}{|c|c|c|c|c|c|}
\hline \multirow{5}{*}{$\begin{array}{l}\text { Ability to } \\
\text { Write High } \\
\text { Procedure }\end{array}$} & \multicolumn{5}{|c|}{ Independence } \\
\hline & & High & Moderate & Low & Total \\
\hline & High & 0 & 2 & 1 & 3 \\
\hline & Moderate & 6 & 12 & 5 & 23 \\
\hline & Low & 1 & 1 & 2 & 4 \\
\hline & Total & 7 & 15 & 8 & 30 \\
\hline
\end{tabular}

The hypothesis being tested is formulated as follows:

- Ho : There is no association between the ability to write procedural texts and independent learning

- $H_{1} \quad$ : There is an association between the ability to write procedural texts and independent learning.

Test criteria: accept Ho, if the sign value. > 0.05. Based on data processing, results are obtained as in Table IV below.

TABLE IV. RESUlTS OF THE ASSOCIATION TEST BETWEEN THE ABILITY TO WRITE PROCEDURE TEXT AND LEARNING INDEPENDENCE

\begin{tabular}{|c|c|c|c|}
\hline & Score & df & Sign. \\
\hline $\begin{array}{c}\text { Pearson Chi- } \\
\text { Square }\end{array}$ & $2.544^{\mathrm{a}}$ & 4 & .637 \\
\hline
\end{tabular}

From Table IV, the sign value is obtained. of 0.637 , because the sign value. $>0.05$, then Ho is accepted, meaning that there is no association between the ability to write procedural texts and independent learning.

\section{B. Discussion}

The results of the data processing above are used to answer the problem formulation, 1) Is the improvement of the students' ability to write procedural text using PBL assisted by serial image media better than using PBL only? 2) Is the increase in student learning independence using PBL assisted by image media series is better than using PBL only?, and 3 ) Is there an association between the ability to write procedural texts and the independent learning of students in the post-test experimental class.

Referring to the results of the data calculation above, the sign value is obtained. (1-tailed) of 0.00 , because of the sign value. $<0.05$, so Ho is rejected, which means the increase in the ability to write the procedural text of students whose learners use PBL assisted by serial image media is better than PBL only. The $\mathrm{N}$-gain average value of the ability to write procedural text for the PBL class assisted by serial image media is 0.67 and for the PBL class, only the average value is 0.52 . There is a difference of 0.15 . Thus, using the PBL assisted by serial image media can improve the writing skills of seventh-grade students instead of using PBL only. This is consistent with research that shows the influence of the PBL model assisted by serial image media on students' text writing ability [18]. A similar type of research using the PBL model can improve the quality of students' procedural text writing [19]. There is an increase in the ability to write procedural texts with the PBL in accordance with focuses on the root of the problem and solving problems, students are faced with problems related to the realities of life so that they do not only learn areas of knowledge, but also experience and feel [9]. The use of serial image media, the ultimate goal of the learning process is achieved, namely the learning outcomes of the ability to write procedural text increase.

Meanwhile, from Table II, the sign value is obtained. (1tailed) of $0.00 / 2=0.000$, because of the sign value. $<0.05$ means the increased learning independence of students whose learners use PBL assisted by serial image media is better than PBL only. These results are consistent with research that shows an increase in learning independence through problembased learning [20], other studies also show the same thing an increase in learning independence through problem-based learning [21]. About learning independence, Sumarmo reported that students who had high learning independence showed: a) tended to learn better under their own supervision than under program supervision, b) were able to monitor, evaluate, and organize their learning effectively; c) save time in completing the task; and d) manage study and time efficiently [21].

From Table IV, the sign value is obtained. of 0.637 , because the sign value. $>0.05$, meaning that there is no association between the ability to write procedural texts and independent learning. This refers to Afandi explaining that at least one of the causes for the low independence of learning is the learning system that does not require students to take an active role in finding the information needed in the learning process [8]. In other words, students have not shown independent learning because the learning system implemented by the teacher has not required students to play 
an active role, students have not been able to. However, the results of this study are different from research which shows a relationship between independent learning and students' ability to write texts [22]. Likewise, other research shows that there is a significant influence between independent learning on students' text writing skills [23].

\section{CONCLUSION}

The N-Gain value of the ability to write procedural text and the independent learning of students in the experimental class using PBL assisted by serial image media is better than the value of the ability to write procedural texts and the learning independence of students in the control class using PBL only. This shows that the PBL assisted by picture media is successful in improving students' skills in writing procedural texts and fostering student learning independence. Although there is no association between the ability to write procedural texts with students' learning independence. For further research, it is hoped that the learning process with the PBL can be applied in fostering other psychological factors. Likewise, the improvement of hard skills and soft skills in Indonesian language learning must be continued so that students are accustomed to implementing them in the learning process in the classroom. In this way, students will grow who are not only smart academically but also students with character.

\section{ACKNOWLEDGMENT}

This article is the result of research at the IKIP Siliwangi Postgraduate Program. My gratitude goes to Prof. Dr. H. Heris Hendriyana, M.Pd as the Chancellor of IKIP Siliwangi, M.Pd, Principal of SMP Negeri 2 Cimahi, Indonesian Language Teacher and Grade VII Student of SMP Negeri 2 Cimahi, Prof. Dr. Euis Eti Rohaeti, M.Pd and Dr. Asep Ikin Sugandi, M.Pd for guiding and helping with this research. Also, I thank colleagues who supported this independent research.

\section{REFERENCES}

[1] Z. Zainurrahman, Menulis: Dari Teori Hingga Praktik (Penawar Racun Plagiarism). Bandung: Alfabeta, 2013.

[2] K. Syamsi, "Model Perangkat Pembelajaran Menulis Berdasarkan Pendekatan Proses Genre Bagi Siswa SMP," Litera, vol. 11, no.2, pp. 288-297, 2012.

[3] E. Sarimanah, F. I. Dewi, R. Efendi, S. Suhendra, M. Nurul, and S. Soeharto, "The Implementation of Discovery Learning Models in Enhancing Speech Script Writing Skills for Students," Ling. Cult., vol. 13, no.2, pp. 145-150, 2019.

[4] E.Kosasih dan E. Kurniawan, Jenis-Kenis Teks; Fungsi, Struktur, dan Kaidah Kebahasaan. Bandung: Yrama Widya, 2016.

[5] S. Suherli dkk, Bahasa Indonesia. Jakarta: Kemdikbud, 2017.9.

[6] R. Sartika, "Problem-Based Module Validation for Complex Prosedure Text," GramatikaJurnal Penelit. Pendidik. Bhs. dan Sastra Indones., vol. 6 , no. 2 , pp. 240-248, 2020.
[7] J. Susilo and V. E. Wahyuni, "Penggunaan Metode Demonstrasi Problem Based Learning (PBL) Untuk Meningkatkan Keterampilan Menulis Teks Prosedur,” Bahastra, vol. 39, no. 2, pp. 61-68, 2019.

[8] L. N. Aulia, S. Susilo, and B. Subali, "Upaya Peningkatan Kemandirian Belajar Siswa dengan Model Problem-Based Learning Berbantuan Media Edmodo,” J. Inov. Pendidik. IPA, vol. 5, no. 1, pp. 69-78, 2019.

[9] W. Widiasworo, Strategi dan Metode Mengajar Siswa di Luar Kelas Secara Aktif, Kreatif, Inspiratif, dan Komunikatif. Yogyakarta: ArRuzz Media, 2017.

[10] A. Shoimin, 68 Model Pembelajaran Inovatif dalam Kurikulum 2013. Yogyakarta: Ar- Ruzz Media, 2014.

[11] M. D. Kristyanawati, S. Suwandi, and M. Rohmadi, "Peningkatan Keterampilan Menulis Teks Eksposisi Menggunakan Model Problem Based Learning," Sch. J. Pendidik. dan Kebud., vol. 9, no. 2, pp. 192202, 2019.

[12] M. U. Agustin, "Optimalisasi Penerapan Model Pembelajaran ' PBL ' Pada Materi Ajar Teks Eksplanasi Bahasa Indonesia,” Dinamika, vol. 10, no. 2, pp. 1-12, 2020.

[13] E. A. Sieska Afrina, Atmazaki, "Pengaruh Penggunaan Model Problem Based Learning Terhadap Keterampilan Menulis Teks Laporan Hasil Observasi," Pendidik. Bhs. dan Sastra Indones., vol. 6, no. 2, pp. 321328, 2017.

[14] D. Yesica and Rosmaini, "Efektivitas Model Pembelajaran Berbasis Masalah (Problem Based Learning) Terhadap Kemampuan Memproduksi Teks Deskripsi Pada Siswa Kelas Vii Smp Negeri 9 Medan Tahun Ajaran 2016/ 2017,”pp. 93-101, 2017.

[15] M. R. Widiastuti,S.Santosa, "Penerapan Model Pembelajaran Problem Based Learning Disertai Media Gambar Untuk Meningkatkan Kemandirian Belajar Siswa dalam Pembelajaran Biologi di SMA Negeri 3 Surakarta Tahun Ajaran 2009/2010," in Seminar Nasional Pendidikan Biologi FKIP UNS 2010, 2010, pp. 333-341.

[16] D. S. Sari and K. H. Sugiyarto, "Pengembangan Multimedia Berbasis Masalah Untuk Meningkatkan Motivasi Belajar dan Kemampuan Berpikir Kritis Siswa,” J. Inov. Pendidik. IPA, vol. 1, no. 2, pp. 153166, 2015.

[17] A. I. Sugandi, "Pengaruh Pembelajaran Berbasis Masalah dengan Setting Kooperatif Jigsaw Terhadap Kemandirian Belajar Siswa SMA,” Infin. J., vol. 2, no. 2, pp. 144-155, 2013

[18] A. Hizati and E. Arief, "Pengaruh Model Problem Based Learning Berbantuan Media Gambar Berseri Terhadap Keterampilan Menulis Teks Eksplanasi Siswa Kelas VIII SMP Negeri 12 Padang," J. Pendidik. Bhs. dan Sastra Indones., vol. 1, no. 7, pp. 183-190, 2018.

[19] J. Ernawati and H. Budiyono, "Penerapan Model Pembelajaran Berbasis Masalah Untuk Meningk atkan Kualitas Pembelajaran Menulis Teks Prosedur," Dikbastra, J. Pendidik. Bhs. dan Sastra, vol. 1, no. 1, pp. 38-53, 2018.

[20] F. E. Subekti and A. Jazuli, "Peningkatan Kemampuan Pemecahan Masalah dan Kemandirian Belajar Mahasiswa Melalui Pembelajaran Berbasis Masalah," Jurnal Nas. Pendidik. Mat., vol. 4, no. 1, pp. 1315, 2020.

[21] F. Rinanda, M. Ikhsan, and H. Sofyan, "Kemandirian Belajar Siswa SMP Melalui Model Problem Based Learning (PBL)," J. Peluang, vol. 7, no. 2, pp. 121-128, 2019.

[22] E. Rismasellia, "Model Discovery Learning dalam Pembelajaran Menulis Kreatif Cerita Fantasi dan Hubungannya dengan Kemandirian Belajar Siswa Kelas VII di SMP Negeri 1 Jatisari Kota Karawang," Wistara, vol. 1, no. 2, pp. 190-198, 2018.

[23] Liliswati, "Pengaruh Minat dan Kemandirian Belajar terhadap Kemampuan Menulis Narasi," Diskurs. J. Pendidik. Bhs. Indones., vol. 2, no. 2 , pp. $180-188,2019$ 